\title{
First record of a specimen of the shortbill spearfish Tetrapturus angustirostris Tanaka, 1915 in the Pacific coast of Mexico
}

\author{
José De La Cruz-Agüero ${ }^{1}$, Rogelio González-Armas ${ }^{1}$ \\ Francisco Javier García-Rodríguez ${ }^{1}$ \& Víctor Manuel Cota-Gómez ${ }^{1}$ \\ ${ }^{1}$ Departamento de Pesquerías y Biología Marina, Colección Ictiológica, Instituto Politécnico Nacional \\ Centro Interdisciplinario de Ciencias Marinas (CICIMAR-IPN) \\ La Paz, Baja California Sur, México \\ Corresponding author: José De La Cruz-Agüero (jcruz@ipn.mx)
}

\begin{abstract}
The shortbill spearfish Tetrapturus angustirostris Tanaka, 1915 is a widespread tropical and temperate species but is relatively rare, with very few published or cataloged records in museums and fish collections. We reported for the first time a specimen of $T$. angustirostris from the Pacific coast of Mexico, including meristic, morphometric and molecular data, which was caught in the vicinity of Los Cabos, Baja California Sur, Mexico, in November 2015.
\end{abstract}

Keywords: Tetrapturus angustirostris; voucher specimen; mitochondrial DNA; COI; mtCR; Cape San Lucas; Baja California

\section{INTRODUCTION}

The shortbill spearfish Tetrapturus angustirostris Tanaka, 1915 is widely distributed throughout the tropical and temperate seas but rarely seen or captured compared to the rest of the billfishes. In the eastern Pacific, this species is found from California, USA, and the mouth of the Gulf of California to Peru, including all of the oceanic islands (Nakamura, 1985). This species is oceanic, epipelagic, offshore and deep-water, but is infrequently encountered by anglers in most parts of their range, or some cases are taken as by-catch by commercial longlines and secondarily in purse-seines and trolling (Kitchell et al., 2006; Marín-Enríquez \& Muhlia-Melo, 2018).

The primary distinguishing feature which separates all four spearfish species (Tetrapturus spp.) from marlins and sailfish is the position of the anus, or "vent." In all spearfishes, the anus is located well in front of the base of the first anal fin (at least as far forward of the anal fin as the longest spine of that fin), whereas in the other billfish the vent is located close to the anal fin (Pepperell, 2010). Other characteristics are a slender, lightweight body, short bill and a dorsal fin that is highest anteriorly (greater than in marlin and lower than in the sailfish).

The shortbill spearfish T. angustirostris is listed in Annex I of the 1982 Convention on the Law of the Sea and in the Red List as Data Deficient (Collette et al., 2011). However, there is little scientific information available about its biology and ecology (see Nakamura 1985).

According to with all available information (see below), despite its relatively small size among the billfish that would make it susceptible to being cataloged (normal length around $190 \mathrm{~cm}$ of total length (TL); Nakamura, 1985), there are scarce records of the shortbill spearfish for the eastern Pacific listed in museums or fish collections worldwide. In this regard, billfish specialists have claimed the lack of voucher specimens and their associated metadata (i.e., molecular sequences, photographic images and GPS coordinates) which complicates the issue of species delineation, as some of these populations may also merit recognition as subspecies (Hanner et al., 2011). In the same sense, given the strong morphological similarity of the billfishes, questionable identifications require reexamination with additional morphological and molecular data.

Corresponding editor: Guido Plaza 
Particularly, in the Exclusive Economic Zone (EEZ) of Mexico (Pacific basin), the shortbill spearfish has been cited recently in several species' checklists (e.g., for the Revillagigedo Islands: Castro-Aguirre \& BalartPáez, 2002; Del Moral-Flores et al., 2016; Fourriére et $a l ., 2016)$. These works are based mainly on the results from the first ichthyological explorations date back to the late $19^{\text {th }}$ and $20^{\text {th }}$ centuries (e.g., Jordan \& McGregor, 1899; Snodgrass \& Heller, 1905; Ricker, 1959) and museological online databases. However, in all those checklists the inclusion of the species, i.e., $T$. angustirostris, has been made without confirmation of its presence and verification of voucher specimens. This is the same case of the observers aboard the fishing fleets where, due to the nature of the work, the registration of incidental fishing species (such as that of the shortbill spearfish) is made without the collection of specimens for their deposit and cataloging in museums or scientific collections (e.g., Marín-Enríquez \& Muhlia-Melo, 2018). In the present case, the existence and availability of a voucher specimen acquire greater relevance if one considers that the holotype of the species (formerly in the Zoology Department of Tokyo University Museum: ZUMT4187) has been lost (Fricke et al., 2019).

A specimen of $T$. angustirostris caught on the Pacific coast of Mexico was registered for the first time, including meristic, morphometric and molecular data.

\section{MATERIALS AND METHODS}

On November 19, 2015, one specimen of Tetrapturus angustirostris (Fig. 1) was caught off Cabo San Lucas,

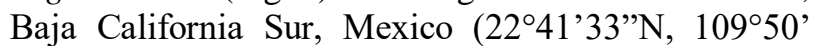
33 ”W) aboard the "Shambala" $60 \mathrm{ft}$ Hatteras yacht, captained by Ignacio "Nayo" Winkler. The fishermen used a trolling with a $30 \mathrm{lbs}$ line and using circle hooks and Pacific sardine (Sardinops sagax) as bait. The shortbill spearfish was photographed in situ and then kept frozen within in the facilities of the "Pisces Fleet" at Cabo San Lucas, B.C.S. (http://www.piscessportfishing.com). In December 2015, it was defrosted, weighted and identified firstly by both meristic and morphometric characters, which were taken following standard procedures, used in other descriptions of billfishes (Rivas, 1956; Robins, 1974; Nakamura, 1985).

These counts and measurements are presented in Table 1, which were made on the left-hand side of the body the latter recorded to the nearest $0.1 \mathrm{~cm}$. Before preservation, a small piece of muscle tissue from the pectoral left side was preserved in $96 \%$ ethanol for molecular analyses. After that, the specimen was fixed in formalin and later transferred to $70 \%$ ethyl alcohol for preservation and deposited in the fish collection (CI) of the Centro Interdisciplinario de Ciencias Marinas (CICIMAR-IPN), in La Paz, B.C.S., Mexico, with the catalog number CICIMAR-CI 8328 (http:// coleccion. cicimar.ipn.mx). Sex and maturity could not be established because it was not gutted for a better condition of conservation.

Three of the four recognized species of shortbill spearfish: T. angustirostris Tanaka, 1915, T. belone Rafinesque, 1810, and T. pfluegeri Robins \& de Sylva, 1963, show highly similar DNA sequences and are not unambiguously distinguishable by barcodes alone (Hanner et al., 2011). Consequently, to complete such metadata and recheck our identification, we supported the meristic and morphometric data using genetic information.

A total DNA was extracted from a muscle tissue sample using the QIAGEN $^{\odot}$ DNeasy Blood and Tissue kit (Catalogue $\mathrm{N}^{\circ} \mathrm{Q} 01-69506$, Hilden, Germany) following the manufacturer's protocol. Hanner et al. (2011) used the Cytochrome Oxidase subunit I (COI) to explore the Tetrapturus spp. complex. Besides, Collette et al. (2006) discovered that the control region ( $\mathrm{mtCR}$ ) could be used to support the discrimination and to recognize among these species. Thus, these two fragments of the mitochondrial DNA (mtDNA) were amplified by Polymerase Chain Reaction (PCR). For the COI, it was used the primers FishF2 and FishR2 (Ward et al., 2005); and for the $\mathrm{mtCR}$, the primers Pro5 M13-F and D-loop (Collette et al., 2006). Each reaction was made using a $35 \mu \mathrm{L}$ volume containing: $1 \mathrm{X}$ of PCR Buffer $\left(\mathrm{MgCl}_{2}\right), 0.2 \mathrm{mM}$ of dNTP mix, $0.48 \mu \mathrm{M}$

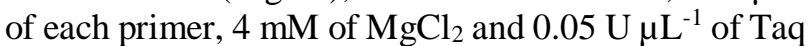
DNA polymerase (Invitrogen ${ }^{\odot}$, Carlsbad, CA, USA). An amount of $0.7 \mu \mathrm{L}$ of total DNA was included in each reaction. Thermal cycler conditions for amplification consisted of an initial phase of $2 \mathrm{~min}$ at $94^{\circ} \mathrm{C}$, followed by 35 cycles, and a final extension for $4 \mathrm{~min}$ at $72^{\circ} \mathrm{C}$. Each of the 35 cycles consisted of three steps: a) $1 \mathrm{~min}$ at $94^{\circ} \mathrm{C}$; b) $1 \mathrm{~min}$ at $58^{\circ} \mathrm{C}$ for 12 and $16 \mathrm{~s} ; 1 \mathrm{~min}$ at $66.5^{\circ} \mathrm{C}$ for $\mathrm{mtCR}$, and $30 \mathrm{~s}$ at $54^{\circ} \mathrm{C}$ for $\mathrm{COI}$; and c) 2 min at $72^{\circ} \mathrm{C}$. The PCR products were visualized on $1 \%$ agarose gels before purification and sequencing, using forward and reverse primers for each gene (Macrogen ${ }^{\odot}$, Seoul, Korea).

Sequences were arranged and edited in Sequencher 4.5 software (Gene Code, Ann Arbor, MI). Basic Local Alignment Search Tool (BLAST, https://blast.ncbi. nlm.nih.gov/Blast.cgi) was used to explore the similarity of our sequence with sequences found in GenBank (https://www.ncbi. nlm.nih.gov/genbank/). Since the highest molecular percent identity was found with the Tetrapturus complex, we used sequences of $\mathrm{COI}$ and mtCR deposited in GenBank to detect clades. 


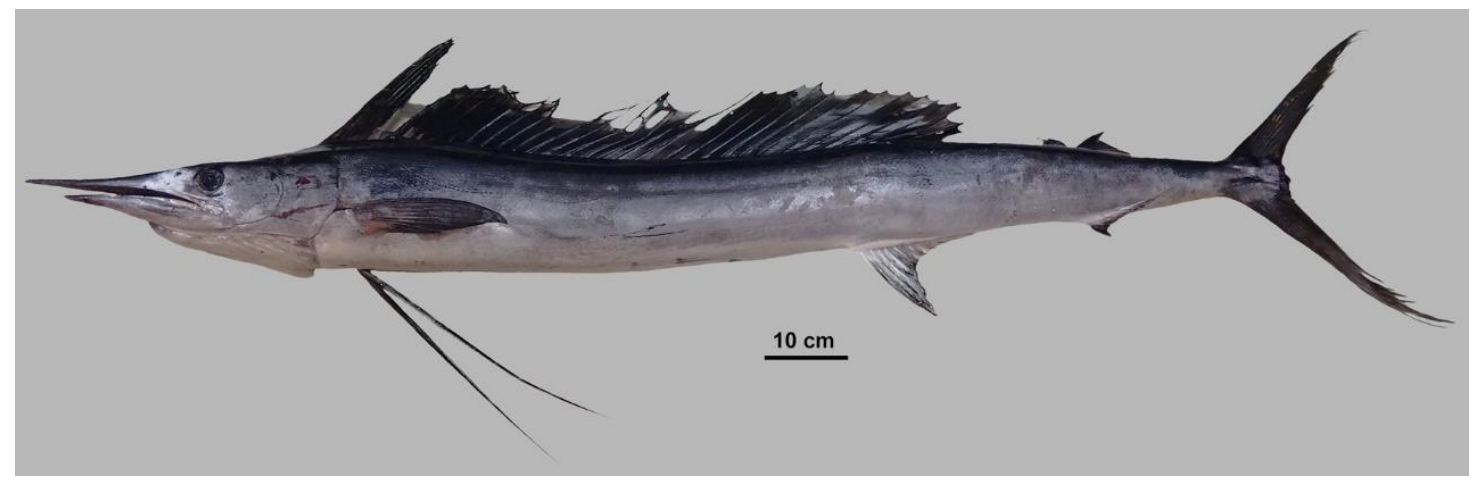

Figure 1. Tetrapturus angustirostris Tanaka, 1915 caught in November 2015, off Cabo San Lucas, Baja California Sur, Mexico. $153.7 \mathrm{~cm}$ body length and $11.650 \mathrm{~kg}$ total weight (CICIMAR-CI-8328).

Table 1. Morphometric and meristic characters of Tetrapturus angustirostris Tanaka, 1915 caught in November 2015, off Cabo San Lucas, Baja California Sur, Mexico (total weight $11.650 \mathrm{~kg}$ ). Measurements expressed in centimeters are as defined by Rivas (1956).

\begin{tabular}{lcc}
\hline \multicolumn{1}{c}{ Measurement/Count } & Abbreviation & T. angustirostris CICIMAR-CI 8328 \\
\hline Body length & BL & 153.7 \\
Body girth & BG & 41.4 \\
Greatest body depth & GBD & 21.2 \\
Head length & HL & 32.9 \\
Snout length & SL & 15.7 \\
Bill length & BIL & 20.3 \\
Length of pectoral fin & PFL1 & 19.2 \\
Length of pelvic fin & PFL2 & 36.3 \\
Length of the second dorsal fin & DFL2 & 6.1 \\
Length of second anal fin & AFL2 & 6.2 \\
Depth of body at origin of first dorsal & DBD1 & 19.5 \\
Depth of body at origin of first anal & DBA1 & 18.1 \\
Width of body at origin of pectoral & WBP1 & 9.7 \\
Width of body at origin of first anal & WBA1 & 9.2 \\
Width of body at origin of second anal & WBA2 & 8.0 \\
Width of caudal peduncle at the keel & WCP & 3.8 \\
Preopercular length & POL & 26.5 \\
Maxillary length & ML & 15.5 \\
Orbit diameter & OD & 4.0 \\
Interorbital width & IOW & 7.6 \\
Tip of the mandible to the tip of the bill & MLB & 5.2 \\
Length of upper caudal lobe & UCL & 29.6 \\
Length of lower caudal lobe & LCL & 29.2 \\
Caudal spread & CW & 49.0 \\
Caudal angle & CA & $126^{\circ}$ \\
Dorsal fin rays & & 46 \\
Anal fin rays & & $12($ IV-8) \\
Pectoral fin rays & & $31-32$ \\
\hline & &
\end{tabular}

Neighbor-Joining (NJ) trees of Kimura two-parameter (K2P) distance (Kimura, 1980), were created to provide a graphical representation of the pattern of divergence between species and for supporting our identification
(Saitou \& Nei, 1987). The robustness of the internal branches of the trees was supported by 1,000 bootstrap replications (Felsenstein, 1985). This analysis was performed with MEGA5 (Tamura et al., 2011). It should 

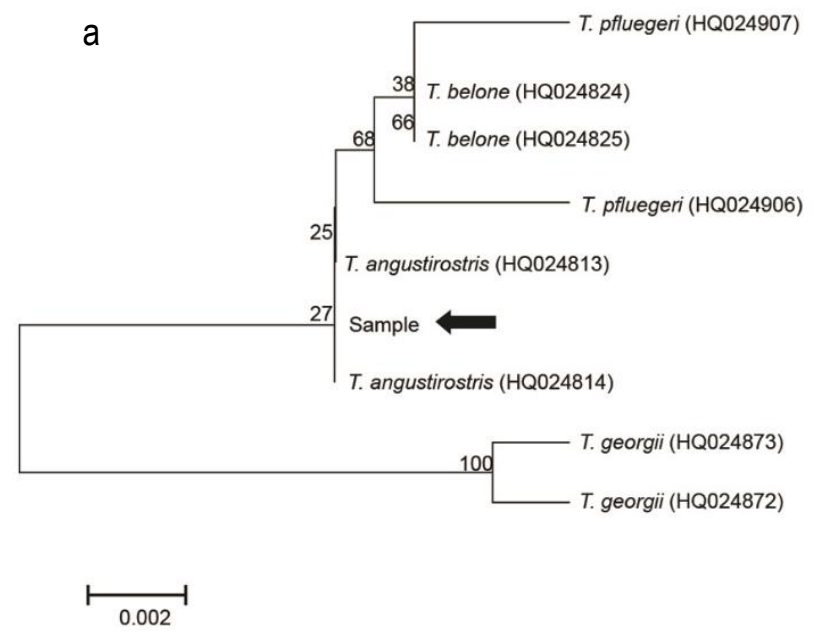

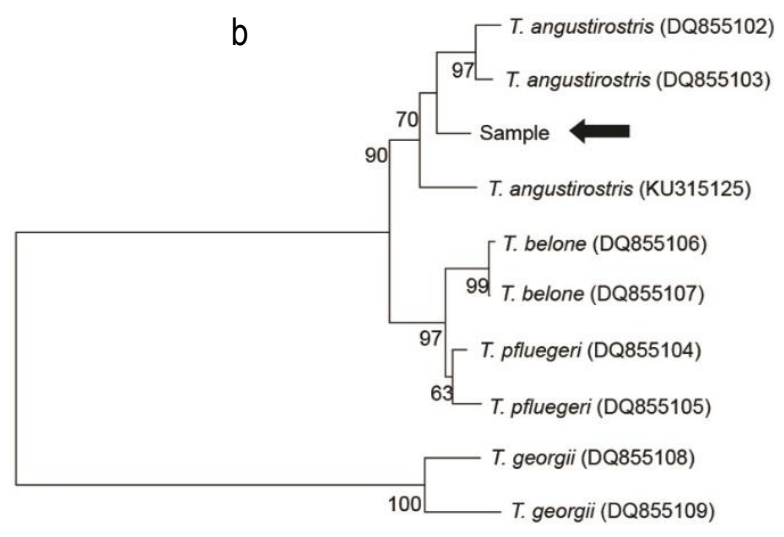

$\longmapsto$

Figure 2. Neighbor-joining tree based on K2P distances of a) Cytochrome Oxidase subunit I (COI) and b) Control Region (CR) sequences of Tetrapturus complex. Numbers associated with the scientific name are the GenBank accession numbers. Arrows indicates our sample.

be noted that the tree depicted (Fig. 2) is not intended as a hypothesis of phylogenetic relationships but merely as a visual representation of haplotype groupings (Hanner et al., 2011).

The specialized literature and several recent bibliographic published were consulted and reviewed deliberately to compare the record from this study with all available distribution information of the shortbill spearfish species (see references). In this way, a clear and cumulative database was compiled with all existing records for T. angustirostris within the eastern Pacific. This database was cross-referenced with information available online from biological collections and museums worldwide. Global databases consulted included the Ocean Biogeographic Information System (OBIS, 2019), the Global Biodiversity Information Facility (GBIF, 2019), and the FishBase Project (Froese $\&$ Pauly, 2019). The spellings in the citations of the common names of the species (English and Spanish, sensu Page et al., 2013) follows Nelson et al. (2002). Finally, interviews with local fishers and fleet owners were conducted by the end of 2015, in Los Cabos, B.C.S. region, to assess if other shortbill spearfish specimens were captured in the same area.

\section{RESULTS}

A picture of the shortbill spearfish is shown in Fig. 1. The specimen $(153.7 \mathrm{~cm}$ body length, $11.650 \mathrm{~kg}$ total weight) was characterized by its body elongate and fairly compressed. The bill is short and slender, round in cross-section. Lower mandible shorter than the upper jaw, but still projecting. Branchiostegal membranes completely united to each other, but free from isthmus. Two dorsal fins, the first with 46 rays and with a pointed anterior lobe, higher than body depth anteriorly; the base of the dorsal fin is long, extending from posterior margin of preopercle to near second dorsal fin origin. Second dorsal fin with six rays, its position slightly backward concerning the second anal fin. Two anal fins, the first with 12 rays (IV-8), and the second with six rays and very similar in size and shape to the second dorsal fin; pectoral fins with 31-32 rays. Pelvic fins slender, about twice the length of the pectorals. Caudal peduncle moderately compressed with double keels on each side and a shallow notch on both dorsal and ventral surfaces. The anus situated far anterior to first anal fin origin, at a distance usually longer than the height of the first anal fin. Lateral line single and well visible. Body densely covered with elongate bony scales, each scale with three to five posterior prolongations. Color: body dark blue dorsally, blue splattered with brown laterally, and silvery white ventrally, without dots or stripes. First dorsal fin dark blue and without dots or blotches; remaining fins brown or dark brown; bases of first and second anal fins often shading with silvery white. Meristic and morphometric characters are presented in Table 1 . We successfully amplified a COI fragment up $677 \mathrm{bp}$ and an mtCR fragment over $902 \mathrm{bp}$. The sequences were deposited in GenBank (accession numbers, COI: MF038038; mtCR: MF038039). The BLAST searches confirmed that one fragment belonged to $\mathrm{COI}$ and the other to mtCR. Finally, the exploration of the museological online databases revealed the existence of seven cataloged 
Table 2. The voucher and reported specimens of the shortbill spearfish Tetrapturus angustirostris Tanaka, 1915, caught in the eastern Pacific Ocean. Data logged in the Global Biodiversity Information Facility (http://www.gbif.org/), the Ocean Biogeographic Information System (http://www.iobis.org/) and the FishBase Project (http://www.fishbase.org/). All accessed in February 2019. LACM: The Natural History Museum of Los Angeles County. CAS: Department of Ichthyology of the California Academy of Sciences. UF: The Florida Museum of Natural History Ichthyology Collection. SIO: Scripps Institution of Oceanography. *Current record in Colección Ictiológica (CI) of Centro Interdisciplinario de Ciencias Marinas del Instituto Politécnico Nacional. B.C.: Baja California. B.C.S.: Baja California Sur.

\begin{tabular}{lccllll}
\hline Institution & Catalog number & $\begin{array}{c}\text { Geographic } \\
\text { Location }\end{array}$ & Country & Locality & $\begin{array}{c}\text { Date } \\
\text { DD/MM/YY }\end{array}$ & Type of the record \\
\hline LACM & 25499 & $19^{\circ} 30^{\prime} \mathrm{N}, 156^{\circ} 00^{\prime} \mathrm{W}$ & USA & off Kona, Hawaii & $13 / 08 / 1985$ & Preserved specimen \\
LACM & 25478 & $19^{\circ} 30^{\prime} \mathrm{N}, 156^{\circ} 00^{\prime} \mathrm{W}$ & USA & off Kona, Hawaii & $16 / 08 / 1985$ & Preserved specimen \\
LACM & 25422 & $19^{\circ} 38^{\prime} \mathrm{N}, 156^{\circ} 00^{\prime} \mathrm{W}$ & USA & off Kailua-Kona, Hawaii & $11 / 08 / 1988$ & Preserved specimen \\
LACM & 25421 & $19^{\circ} 38^{\prime} \mathrm{N}, 156^{\circ} 00^{\prime} \mathrm{W}$ & USA & off Kailua-Kona, Hawaii & $11 / 08 / 1988$ & Preserved specimen \\
CAS & 88961 & $19^{\circ} 28^{\prime} \mathrm{N}, 155^{\circ} 58^{\prime} \mathrm{W}$ & USA & Kealakekua Bay, Hawaii & $28 / 10 / 1973$ & Preserved specimen \\
FishBase & No Data & $30^{\circ} 01^{\prime} \mathrm{N}, 113^{\circ} 31^{\prime} \mathrm{W}$ & Mexico & Upper Gulf of California & $02 / 10 / 1996$ & Unknown \\
UF & $76-341$ & $31^{\circ} 10^{\prime} \mathrm{S}, 110^{\circ} 11^{\prime} \mathrm{W}$ & Chile & off Coquimbo & $15 / 04 / 1958$ & Preserved specimen \\
SIO & 208791 & $29^{\circ} 56^{\prime} \mathrm{N}, 71^{\circ} 19^{\prime} \mathrm{W}$ & International waters & 154 miles off B.C. & $15 / 10 / 1976$ & Preserved specimen \\
* CICIMAR-IPN $^{*}$ CI- 8328 & $23^{\circ} 41^{\prime} \mathrm{N}, 109^{\circ} 50^{\prime} \mathrm{W}$ & Mexico & off Cabo San Lucas, B.C.S. & $19 / 11 / 2015$ & Preserved specimen \\
\hline
\end{tabular}

specimens (plus one without data) from the central and eastern Pacific (Table 2). Although one of these specimens (SIO 76-341) is registered as caught off Baja California Norte, Mexico, that record does not correspond to the country, according to the delimitation of the EEZ of the Mexican Pacific (DOF, 1976), and none of the current specimens have been documented in any reference.

\section{DISCUSSION}

All features of the captured specimen fitted well with the description of Tetrapturus angustirostris available in the literature (i.e., Nakamura, 1985; Pepperell, 2010). T. angustirostris differs from the other Pacific billfishes (e.g., Xiphias gladius, Istiophorus platypterus, Kajikia audax, Makaira spp.) by a number of main characters, such as pelvic fins present, first dorsal fin lower than body depth at level of midbody, not sail like; bill very short (less than $15 \%$ of body length), usually equal to, or shorter than head length, and the anus situated far anterior to first anal fin origin (Nakamura, 1985). The highest nucleotide identity values for the COI were obtained with the $T$. angustirostris or T. pfluegeri (100\%) and for the $\mathrm{mtCR}$ only with T. angustirostris (100\%). Considering genetic information of the species in the Tetrapturus complex, we support that our specimen belongs to the species T. angustirostris (Fig. 2).

However, it is not overlooked that the species-level (alpha) taxonomy of the spearfishes is not well resolved and species identification is difficult, especially in some areas of the eastern north Atlantic where three species may occur sympatrically (McDowell et al., 2018). In this sense, the poor condition of some of the type materials, incomplete descriptions, and the loss or non-designation of type materials have made it difficult to carry out taxonomic studies. Therefore, because of the loss of the holotype, the species Tetrapturus angustirostris Tanaka, 1915 it may require the designation of a neotype.

According to information provided by local fishermen in the south of the peninsula of Baja California, T. angustirostris is rare and uncommon in catches by the sports fishing fleet. The same applies to the tuna purse seine fleet in the tropical eastern Pacific, wherein 23 years and near 425,000 fishing sets, only the incidental catch of 687 individuals were recorded (Marín-Enríquez \& Muhlia-Melo, 2018). So, it is not unusual that there are very few published or cataloged records in museums and fish collections, not only for the shortbill spearfish in the Mexican waters but all spearfishes worldwide, and particularly in the central and eastern Pacific (Table 2). Consequently, it can be said that within the istiophorid billfishes, the spearfishes (Tetrapturus spp.) yet they are the least studied due to their rarity (McDowell et al., 2018). Because there are no particular fisheries for the shortbill spearfish, we expect that data from mitochondrial loci and morphological traits documented herein may be useful to compare to other regions inhabited by the species and for future studies on the relationships among spearfishes. The specimen is available for examination at CI-CICIMAR, and sample muscle or DNA aliquots may be obtained upon request.

\section{ACKNOWLEDGMENTS}

The authors are grateful to the Captain and crew members of the "Shambala" Yacht. Thanks to Jean D. 
Forbes, John Stephens, Robert Jackson, John Pappanastos and Tracy Ehrenberg (Pisces Sportfishing Fleet and ASUPESCA, Cabo San Lucas, B.C.S., Mexico) for the donation of the shortbill spearfish specimen. We appreciate the support of COFAA-IPN, EDI-IPN, and SNI-CONACyT. We thank the anonymous reviewers for their comments and suggestions.

\section{REFERENCES}

Castro-Aguirre, J.L. \& Balart-Páez, E.F. 2002. La ictiofauna de las Islas Revillagigedo y sus relaciones zoogeográficas, con comentarios acerca de su origen y evolución. In: Lozano-Vilano, M.L. (Ed.). Libro jubilar en honor del Dr. Salvador Contreras Balderas. Universidad Autónoma de Nuevo León, Monterrey, pp. 153-170.

Collette, B.B., McDowell, J.R. \& Graves, J.E. 2006. Phylogeny of recent billfishes (Xiphioidei). Bulletin of Marine Science, 79: 455-468.

Collette, B., Acero, A., Canales, C., Carpenter, K.E., Di Natale, A., Fox, W., Miyabe, N., Montano, R., Nelson, R., Schaefer, K., Serra, R., Sun, C., Uozumi, Y. \& Yáñez, E. 2011. Tetrapturus angustirostris. The IUCN Red List of Threatened Species 2011: e.T170315A 6744759. [https://www.iucnredlist.org/species/1703 15/6744759]. Reviewed: 28 February 2019.

Del Moral-Flores, L.F., Gracian-Negrete, J.M. \& Guzmán-Camacho, A.F. 2016. Peces del archipiélago de las Islas Revillagigedo: una actualización sistemática biogeográfica. BIOCYT: Biología Ciencia y Tecnología, 9(34): 596-619.

Decreto Oficial (DOF). 1976. Decreto que fija el límite exterior de la Zona Económica Exclusiva de México. Diario Oficial de la Federación, Estados Unidos Mexicanos, Presidencia de la República, 07/06/1976. [http://dof.gob.mx/nota_detalle.php?codigo $=4845962$ \&fecha=07/06/1976]. Reviewed: 4 January 2019.

Felsenstein, J. 1985. Confidence limits on phylogenies: an approach using the bootstrap. Evolution, 39(4): 783791.

Fourriére, M., Reyes-Bonilla, H., Ayala-Bocos, A., Ketchum, J. \& Chávez-Comparan, J.C. 2016. Checklist and analysis of completeness of the reef fish fauna of the Revillagigedo Archipelago, Mexico. Zootaxa, 4150(4): 436-466.

Fricke, R., Eschmeyer, W.N. \& Van der Laan, R. 2019. Eschmeyer's catalog of fishes: genera, species, references. [http://researcharchive.calacademy.org/research/ichthyology/catalog/fishcatmain.asp]. Reviewed: 28 February 2019.
Froese, R. \& Pauly, D. 2019. FishBase. World Wide Web electronic publication. [http:// www.fishbase.org]. Reviewed: 5 February 2019.

Global Biodiversity Information Facility (GBIF). 2019. The Global Biodiversity Information Facility. [http:// www.gbif.org/]. Reviewed: 10 February 2019.

Hanner, R., Floyd, R., Bernard, A., Collette, B.B. \& Shivji, M. 2011. DNA barcoding of billfishes. Mitochondrial DNA, 22(1): 27-36. doi: 10.3109/19401736. 2011.596833

Jordan, D.S. \& McGregor, R.C. 1899. List of fishes collected at the Revillagigedo Archipelago and neighboring islands. United States Commission of Fish and Fisheries, Report of the Commissioner, 24: 271-284.

Kimura, M. 1980. A simple method for estimating evolutionary rates of base substitutions through comparative studies of nucleotide sequences. Journal of Molecular Evolution, 16(2): 111-120. doi: 10.1007/ BF01731581

Kitchell, J.F., Martell, S.J.D., Walters, C.J., Jensen, O.P., Kaplan, I.C., Watters, J., Essington, T.E. \& Boggs, C.H. 2006. Billfishes in an ecosystem context. Bulletin of Marine Science, 79: 669-682.

Marín-Enríquez, E. \& Muhlia-Melo, A. 2018. Incidental catch of the rare shortbill spearfish (Tetrapturus angustirostris) by the tuna purse seine fleet in the eastern tropical Pacific Ocean. Ciencias Marinas, 44(1): 21-32. doi: 10.7773/cm.v44i1.2727

McDowell, J., Mamoozadeh, N., Brightman, H. \& Graves, J. 2018. Analysis of the alpha-level taxonomy and phylogenetic relationships among billfishes of the genus Tetrapturus. Abstract \#26 in Supplementary data (supplementary material: http://bit.ly/2Xgrg32). In: Kerstetter, D.W. \& Schratwieser, J. (Eds.). Billfishes in a changing world. $6^{\text {th }}$ International Billfish Symposium. ICES Journal of Marine Science, fsy012. doi: 10.1093/icesjms/fsy012

Nakamura, I. 1985. Billfishes of the world. FAO species catalog volume 5, Food and Agriculture Organization, Rome.

Nelson, J.S., Starnes, W.C. \& Warren, M.L. 2002. A capital case for common names of species of fishes - a white crappie or a white crappie. Fisheries, 27: 31-33.

Ocean Biogeographic Information System (OBIS). 2019. Data from the Ocean Biogeographic Information System. [http://www.iobis.org]. Reviewed: 7 February 2019.

Page, L.M., Espinosa-Pérez, H., Findley, L.T., Gilbert, C.R., Lea, R.N., Mandrak, N.E., Mayden, R.L. \& Nelson, J.S. 2013. Common and scientific names of fishes from the United States, Canada, and Mexico. American Fisheries Society, Maryland. 
Pepperell, J. 2010. Fishes of the open ocean: a natural history and illustrated guide. The University of Chicago Press, Chicago.

Ricker, K.E. 1959. Fishes collected from the Revillagigedo Islands during the 1954-1958 cruises of the "Marijean." Institute of Fisheries, University of British Columbia, Vancouver, Canada Museum Contribution, 4: $11 \mathrm{pp}$.

Rivas, L.R. 1956. Definitions and methods of measuring and counting in the billfishes (Istiophoridae, Xiphiidae). Bulletin of Marine Science of the Gulf and Caribbean, 6: 18-27.

Robins, C.R. 1974. The validity and status of the round scale spearfish, Tetrapturus georgei. In: Shomura, R.S. \& Williams, F. (Eds.). Proceedings of International Billfish Symposium. NOAA Technical Reports, pp. 54-61.

Received: 16 March 2018; Accepted: 30 May 2019
Saitou, N. \& Nei, M. 1987. The neighbor-joining method: a new method for reconstructing phylogenetic trees. Molecular Biology and Evolution, 4(4): 406-425.

Snodgrass, R.E. \& Heller, E. 1905. Papers from the Hopkins-Stanford Galapagos Expedition, 1898-1899. XVII. Shorefishes of the Revillagigedo, Clipperton, Cocos and Galapagos Islands. Proceedings of the Washington Academy of Science, 6: 333-427.

Tamura, K., Peterson, D., Peterson, N., Stecher, G., Nei, M. \& Kumar, S. 2011. MEGA5: molecular evolutionary genetics analysis using maximum likelihood, evolutionary distance, and maximum parsimony methods. Molecular Biology and Evolution, 28(10): 2731-2739. doi: 10.1093/molbev /msr121

Ward, R.D., Zemlak, T.S., Innes, B.H., Last, P.R. \& Hebert, P.D. 2005. DNA barcoding Australia's fish species. Philosophical Transactions of the Royal Society B, 360(1462): 1847-1857. doi: 10.1098/rstb. 2005.1716 